\title{
FRANCO-AMERICAN RELATIONS IN THE CONTEXT OF THE LIBYAN WAR 2011
}

The Franco-American relations in the context of the Libyan war were analysed in this article. The author pays attention to the position of the French Republic and the United States regarding the events in the Arab world in 2011 and examines the circumstances of France's leadership in Libyan war. It is mention that the principles of cooperation with Arabic countries and controlling domestic and foreign policy strategies in the Near East and in Northern Africa are of great importance for the leading international relations performers such as the French Republic and the US. But it is necessary to understand that the relations between France and the USA are ambiguous and often inconsistent. Consequently one more check of the firmness of Franco-American relations was the year of 2011. During Arab rebellions the US and the French Republic have demonstrated the power of their partnership and their mutual importance in the world. The fact is that their cooperation has put the end to the M. Gaddafi's dictatorship. The author has analysed the adoption of the resolution 1973, the course of the military operation and its consequences in Libya and the overthrow of M. Gaddafi's regime. Moreover it is considered that the Libyan situation has demonstrated that the French Republic can not only take part in the administration and in the solving of a serious crisis, but can also take the leading role in the Near East and in Northern Africa. Also Franco-American cooperation in military operations in Libya and benefits of the military intervention for France and the U.S. are demonstrated by the author.

Keywords: Franco-American Relations, the resolution 1973, Libyan war, the Near East.

The constant Franco-American rivalry in the Near East concerns both political influence and beneficial economic treaties. Nevertheless, France and the USA remain the leading allies in the area of guaranteeing safety and stability in the given region. At the moment conflicts in the countries of Arab world (who are the main exporters of energy

${ }^{1}$ M. Ph. Jurczak Witaliya Mychajliwna, Institute of History, Politology \& International Affairs of Vasyl Stefanyk Precarpathian National University, tel. (0342) 75-23-51, e-mail: vfraniuk@ mail.ru 
resources at the world market) influence not only political situation, but also economic volatility in the world. That is why establishing advantageous principles of cooperation with Arabic countries and controlling domestic and foreign policy strategies in the Near East and in Northern Africa are of great importance for the leading performers of international relations such as the French Republic and the US.

But it is necessary to mention that the relations between France and the USA are ambiguous and often inconsistent. For example, "the Iraq crisis", the divergence of opinions on Arab-Israeli conflict led to certain dissidence in transatlantic relations. One more check of the firmness of Franco-American relations was the year 2011. "Arab spring" in Egypt, Tunisia, Libya, and later in Syria became a serious trial not only for both performers, but also for the whole international community.

Though, during Arab rebellions the US and the French Republic have demonstrated the power of their partnership and their mutual importance in the world. And the fact that their cooperation has put an end to the M. Gaddafi's dictatorship which lasted 42 years cannot be left unmentioned.

The reaction of the official Paris to the situation in Tunisia and Egypt was quite restrained, that is France had only provided political support for the opposition and had claimed to be ready to provide economic aid for the democratic forces advocating for "freedom march"; at the same time M. Gaddafi's unwillingness to follow his Tunisian and Egyptian colleagues forced France to move on to an open power politics against Libya's leader. This power politics involved both diplomatic and military means. In accordance to the resolution 1970 that dates back to February 26, 2011, United Nations Security Council introduced a row of strict sanctions against Libyan authorities, which included international travel ban for M. Gaddafi, members of his family and his political encirclement, and also arms embargo, freezing Libyan assets in foreign banks and other restrictions. Since February 26, 2011 France had frozen diplomatic relations with Libya ${ }^{2}$.

As for the USA, Tripoli-Washington dialogue has become much more active in recent years, in spite of American-Libyan conflicts. This became possible when in September 2001 Libya had convicted terrorist acts in New York and Washington and had passed over the information about Libyan citizens who were "Al-Qaeda" members to the western special state security forces. The renewal of American-Libyan relations was also facilitated by the Libya's rejection of weapons of mass destruction projects execution in December 2003. Diplomatic relations between Washington and Tripoli, suspended in 1980, were revived in June 2004. The USA revived purchasing Libyan oil, American oil companies got the access to exploitation of Libyan oil fields. Though, despite the improvement in Americano-Libyan relations, the USA supported the position of the French Republic about military intervention in Libya and disapproved M. Gaddafi's cruel rule.

Quite unexpectedly, France together with Great Britain became the initiators of military intervention in Libya, which was especially unexpected when minding flat refusal of the French government to support American intervention in Iraq in 2003. As distinct to French policy in 2003, France took diametrically opposed position in Libyan crisis,

\footnotetext{
${ }^{2}$ Libye: évacuation des ressortissants français (26 février 2011). $<$ http://www.diplomatie.gouv.fr/fr/pays-zones-geo/libye/la-france-et-la-libye/evenements4528/article/libye-evacuation-des-90180>
} 
having the role of its main organizer. Paris was the first to recognize Libyan opposition forces, and supported strongly the acceptance of United Nations Security Council resolution 1973 , which had factually opened the way to military intervention ${ }^{3}$.

And on March 6, 2011 Paris officially supported the creation of National Council of Libya, M. Gaddafi's opposition. By the $11^{\text {th }}$ of March French Republic had already became the first state to recognize this Council the only legitimate government authority in the country ${ }^{4}$. Finally it was the French project to be laid in the foundation of United Nations Security Council resolution 1973 dating back to March the 17, 2011, demonstrating political, economic and military sanctions against Libyan regime ${ }^{5}$.

On the $19^{\text {th }}$ of March, 2011 in Paris there was held a summit, whose participants were representatives of 18 countries and three international organizations (UN, LAS (Arab League), EU), who supported UN Security Council resolution 1973.

On the same day exactly French air forces, due to agreement with Washington and London, directed the first air strike on the Libyan army ${ }^{6}$. Since this very day an operation called "Odyssey Dawn", was launched by NATO coalition forces, including the USA, France, Great Britain, Canada, and Italy. Later the operation was joined by Belgium, Spain, Denmark, Norway, and Qatar. The US President B. Obama specified the fact that the operation had been of limited military nature aiming to protect the peaceful population of Libya ${ }^{7}$.

And on March 20 the Libyan cities of Tripoli, Misrata, Benghazi and Zuvar suffered bombardments. Rebels greeted allies' actions. Libyan official authorities blamed the West of "barbarian strikes" on military and public objects, that resulted in numerous victims, and the UN - of "outbreak of aggression against Libya".

The officially claimed goals of participating in Libyan operation were announced by the President of the USA in several days after the start of bombardments, when a number of American Congressmen had accused him of saying nothing about the already begun military campaign. B. Obama noted immediately: "Some countries may ignore committed in other states. But the USA is not the one", “... preventing the victory of tyrant Gaddafi over the opposition is one of the strategic interests of the US". Though, American president specified that the US has no intention to repeat the flow of Iraq war, which lasted for eight years, took away thousands lives of Americans and Iraqis and almost a trillion US dollars. But the answer to the question why the American aircrafts had bombarded exactly Libya, but not Yemen or Bahrain, for instance, where the protests were also cruelly suppressed, was not provided by B. Obama's administration. B. Obama took over the government at the period of antiwar disposition of the American society and tried to change the Arab direction of foreign policy of his predecessor George Bush. In

\footnotetext{
${ }^{3}$ T. Zvereva, Sarkozy. Kaddafy, Meždunarodnaja žyzń, 2011, no. 5, pp.79-94.

${ }^{4}$ Création du Conseil national libyen (6 mars 2011). <http://www.diplomatie.gouv.fr/fr/pays-zonesgeo/libye/la-france-et-la-libye/evenements-4528/article/creation-du-conseil-national>

Libye: histoire secrète de la resolution, Le Nouvel Observateur, 22.03.2011. <http://globe.blogs.nouvelobs.com/archive/2011/03/23/libye-histoire-secrete-de-la-resolution1973.html>

${ }^{6}$ J.-Ch. Notin, La vérité sur notre guerre en Libye, Fayard, 2012, 583 p.

${ }^{7}$ L. Snežanova Vojna v Lyvyy kak očerednoj ýtap peredela myra, Nacyonal'nüj ynstytut razvytyja sovremennoj ydeolohyy, M, 2011. p.29.
} 
addition, according to the survey conducted in the USA most Americans were against any interference of their country into Libyan affairs.

That is why the role of initiator of military campaign in Libya was taken by the French Republic. Experts considered the following versions of intervention into the Libyan war. Firstly, this was the expression of NATO member countries solidarity in the case of threat to one of them. And B. Obama stated the possibility of such a threat on February 26, 2011: "I have defined that Gaddafi's actions, the actions of his administration and his closest allies and the actions against Libyan people, pose a great threat to national security and foreign policy of the USA". Secondly, this was the willingness of French Republic to raise its rating using the old tested way of achieving this - the way of "a little victorious war". 8

So the main part of Gaddafi deposing campaign was to be executed by France and Great Britain. Before the opening of international conference concerning Libya, which took place in London on March 29, 2011, N. Sarkozy and D. Cameron issued a statement that M. Gaddafi was to go out of office immediately, and encouraged his adherents to stop supporting him, while it was not too late yet. In accordance with conference results, delegations of 40 countries, including American, French and Italian foreign affairs ministers, the United Nations and NATO Secretaries-General, leaders of Arab league and African Union, draw the following conclusion: M. Gaddafi should resign and leave the country. And on March 15 a communiqué of B. Obama and British and French leaders was promulgated. The article directly announced that the goal of bombardment was overthrowing of the colonel's regime: "NATO must carry on the operation in Jamahiriya till Gaddafi resigns, to keep civilians protected".

A French publication "Le Figaro" noted that presidents of the US and the French Republic unanimously consider it to be "impossible to imagine Libya's future with $\mathrm{M}$. Gaddafi in the role of its leader".

Though, the American public opinion survey showed that most Americans were tired of wars in Afghanistan and Iraq had advocated for non-intervention in Libya affairs. In March 2011 hitting M. Gaddafi's army with air-launched weapons was supported by 32\% of questioned people and $62 \%$ of them were against this. $22 \%$ of those questioned stood for the departure of American ground forces to Libya and 78\% - against it. Only 23\% Americans thought that the US must occupy the "leading role" in Libya and 74\% considered that this "must be done by other countries" 9 . B. Obama, whose popularity level kept decreasing because of the bad economy situation in the country, could not ignore such people's opinions. That is the reason why the USA announced that they would have secondary role in Libyan war. So Washington shifted the expenses and the political responsibility for Libyan war on its European allies. It resulted into creation of multisided coalition led by NATO, and B. Obama's administration occupied the position of "leadership from behind".

\footnotetext{
${ }^{8}$ L. Snežanova Vojna v Lyvyy kak očerednoj ýtap peredela myra, Nacyonal’nüj ynstytut razvytyja sovremennoj ydeolohyy, M, 2011. p.29.

${ }^{9}$ Rohova N. Polytyčeskye posledstvyja voennüx dejstvyj v Lyvšy v otnošenyjax meždu yspolnytelnoj y zakonodatel'noj vlastju v SSA, Rossyja y Ameryka v XXI veke. Ýlektronnüj naučnüj žurnal, 2011. <http://www.rusus.ru/?act=read\&id=290>
} 
It should be mentioned that during the conflict between M. Gaddafi and the Libyan opposition the leaders of the USA and France issued a statement about imposition of sanctions on the leader of the state, his family members and government. The US stopped the diplomatic mission in Tripoli ${ }^{10}$. Such arrangements prove a common Franco-American desire to solve the problem. Though, there were certain intrigues concerning resolution 1973 compiling. Washington wanted the authorship of this resolution, which was the first in the history to sanction air strikes for the sake of "civil population protection", to belong to the USA. But exactly Paris became the first one to announce that France was ready to launch a military operation against M. Gaddafi if there appeared a necessity.

Despite this fact, Washington-Paris coordination was observed during the Libyan crisis. Americans understood that France was a politically decisive ally, who was capable of proving funds necessary for resolving Libyan situation, and French aircrafts, helicopters and ships took part in one third of the operation in Libya.

"In the future the EU will have more important role than the US in securing firm safety in Northern Africa and in the Near East", said the president of France, N. Sarkozy ${ }^{11}$. Delivering a speech in front of French ambassadors, who gathered in Paris on August 31, 2011, French leader said that the war in Libya is a "lesson" for the EU foreign policy: "For the first time Europeans had shown that they are able to interfere into the open conflict...". He added that the war in Libya in which the initiative was taken by France and Great Britain with the support of the USA manifested a new work division between the EU and the US: "The world is changing... President B. Obama presented a new vision of American military cooperation, that includes Europe and the United States cooperation concerning the Arab world".

N. Sarkozy noted that the EU also had to participate more actively in Arab-Israeli conflict. "The role of the USA in the Near East peace process is irreplaceable, but everyone understands that it is not enough. It's necessary to widen the number of negotiations participants... We have to remember that the EU is the main economic partner of Israel and the leader of donor help for Palestinian" ${ }^{\prime 2}$.

But it is important to pay attention to the fact that the interest of the White House administration in the Libyan war leads to the consideration that NATO military intervention in Libya is a hidden factor of raising the US economy. According to paragraphs 17, 19, 20 and 21 of the United Nations Security Council resolution 1970, and paragraphs 19, 20, 21 of the United Nations Security Council resolution 1973, the US government froze about 30 billion dollars that constitute actives of M. Gaddafi and his family. The interesting fact is that the money frozen by the officials are the payments due to obligations of the US state loan, American debts ${ }^{13}$.

10 Olaśuk N. Livija ta Syrija: blyźkosxidnyj vektor u spivrobitnyctvi SŠA-JeS. <http://naub.oa.edu.ua/2012/liviya-ta-syriya-blyzkoshidnyj-vektor-u-spivrobitnytstvi-ssha-es/>

${ }^{11}$ France: Libya war marks new chapter in EU-US relations.

<http://euobserver.com/defence/113486>

${ }^{12}$ France: Libya war marks new chapter in EU-US relations.

<http://euobserver.com/defence/113486>

${ }^{13}$ Resolution 1973 (2011). <http://www.securitycouncilreport.org/atf/cf/\%7B65BFCF9B-6D274E9C-8CD3-CF6E4FF96FF9\%7D/Libya\%20S\%20RES\%201973.pdf> 
Owing to military actions in Libya M. Gaddafi's government was overthrown, and the state administration passed over to pro-American opposition forces - National Transitional Council (NTC), headed by the former Minister of Justice Mustafa Abdul Jalil. As follows from paragraph 10 of the United Nations Security Council resolution $2009(2011)^{14}$, the USA in its turn actively started to lend support for the Libyan provisional government, deblocking and returning assets in small parts back to the country, giving Libyan opposition access to the part of M. Gaddafi's funds. In K. Levyna's opinion, by doing so the White House clearly counted on the possibility that under conditions of revolution fuss there wouldn't be enough time for collecting the main amount of debt and percentages from the USA, and that the debt would be zeroed out because of illegitimacy of M. Gaddafi's government. Even if one presumes that new Libyan republic would become legal successor of Great Socialist People's Libyan Arab Jamahiriya, Vienna Convention on Succession of States in Respect of State Property, Archives and Debts 1983 does not regulate transition of main debt and percentage collection from a third country from the state-predecessor to the state-successor. In such a way the US, stimulating the conflict in the Northern Africa, took all the responsibilities for repaying the debt off themselves, and reduced the external debt by doing it.

But it is wrongly to think that zeroing out the debt, held by Libya, through financing rebels' armed forces is the only way to reinforce post-crisis economy of the United States. Oil reserves in Libya reach 46,4 billion barrels, which constitute 3,4\% of the world reserves (Libya is at the 8th place in the world rating of countries owning oil). Except this, the French company "Total", that owns small amount of Libyan oil reserves, should not be forgotten. A Franco-American coalition, directed to overthrowing M. Gaddafi's regime, occupation Libyan oil fields and liquidation competitors in oil sector, was formed as a result of this.

So Libyan civil war was advantageous for the USA and for the French Republic not only because of possibility of gaining free access to Libyan oil and M. Gaddafi's assets, but also because of getting control over Libyan central bank system. Jamahiriya comparing to Northern Korea, Iran, Sudan, Cuba is a country that does not have Central bank of Rothschild model. Therefore trade trough Libyan central bank not belonging to International Monetary Fund proceeds with help of Libyan dinars not US dollars ${ }^{15}$. Respectively, through getting control over Central Bank of Libya and transferring trade into dollar system, the USA would reduce their financial wastes caused by the differences of dollar to dinar ratio, and would increase the turnover of dollars not secured by assets ${ }^{16}$.

Thus, having analyzed the main reasons for the Libyan war, having observed certain interest of the USA in stimulating armed conflict and having estimated the advantages of the revolution for the state's economy, it may be surely claimed that the conflict in Libya

\footnotetext{
${ }^{14}$ The National Security Strategy of the United States of AmericaThe National Security Strategy of the United States of America. 〈http://www.informationclearinghouse.info/article2320.htm>

${ }^{15}$ Libya: Oil, Banks, the United Nations and America's Holy Crusade. Felicity Arbuthnot. Global Research. < http://www.globalresearch.ca/index.php?context=va\&aid=24151>

${ }^{16}$ Levyna K. Revolucyja v Lyvyy kak ynstrument stabylyzacyy ýkonomyky SŠA [Tekst], Molodoj učenüj, 2011, no.11. T.2, S. 34-36.
} 
was initiated and stimulated be the White House administration in order to reduce the effects of Global Financial Crisis and to stabilize post-crisis economy of the country.

Though, the fact that Libya was in a difficult situation till the mid-April 2011 should be mentioned. None of the sides was prevailing in the war. The coalition forces defended the cities controlled by the rebels from attacks of M. Gaddafi's army but they could not execute offensive operations. For these actions they needed effective air-ground forces, while the rebels did not possess the required military education. M. Gaddafi's positions were strong in the Western part of the country. The colonel lacked finances and political influence to maintain an excellently educated army consisting of Libyan and of hired soldiers from all over Africa as well ${ }^{17}$. The population of Western territories supported the colonel and having faced the threat of being buries under NATO bombardments and the lack of provisions, people valued stable pre-revolution life even more.

And till the mid-August rebel subdivisions were situated already $40 \mathrm{~km}$ away from Tripoli. They succeeded in taking oil refinery and in cut off Tripoli, which supplied M. Gaddafi's army with goods and fuel materials, from Tunisia. As a result of blockades in Tripoli electricity was regularly cut off, prices for goods rose 1,5-2 times as much, and prices for fuel increased almost 30 times as much, which caused indignation of Libyan people.

Anticipating the victory, the rebels worked out "political strategy" of their actions after M. Gaddafi's overthrowing. The document consisted of 37 articles. Immediately after the victory the headquarters was decided to be moved from Benghazi to Tripoli and it was also decided to appoint the government, which would organize the meeting of the socalled National Transitional Council in 8 months. It would work on the developing of the new Constitution project. After the confirming of the final project, it would be put to a referendum within 30 days. National Transitional Council was to develop the project of elective legislation and in accordance with it the date of the new general elections would be appointed.

Having happened to be on the edge of defeat, the sponsors of Libyan revolution had to violate United Nations Security Council resolution and to launch air-ground operation. At the end of August British special force SAS, French Foreign Legion and Qatar's Special Forces were thrown to storm Libyan capital. And in the end of October, after $\mathrm{M}$. Gaddafi's murder, the war was finally over.

Having ignored the downright assassination of the colonel, European leaders congratulated Libyan people on a great victory. "Gaddafi's disappearance is an important stage of the struggle which the Libyan people have been leading for more than eight months to set themselves free from severe 40-year dictatorial regime", said N. Sarkozy, the president of France. And as follows from the words of American president M. Gaddafi's liquidation "manifests the end of the long and painful period in the life of Libyan people", in which during four decades "basic human rights were broken, innocent citizens were put in jail and murdered and beaten, the country's resources were unreasonably spent, terror was used as political weapon"18.

\footnotetext{
${ }^{17}$ J.-Ch. Notin, La vérité sur notre guerre en Libye, Fayard, 2012, 583 p.

${ }^{18}$ H. Myrzajan, Syryjskyj ýtap "Arabskoj vesnü": vojna vmesto modernyzacyy. $<$ http://www.rusus.ru/?act=read\&id=324>
} 
So the international operation in Libya finished in the end of October 2011, when the United Nations Security Council resolution 2016 was unanimously adopted. The resolution presupposed the dismissal of the zone closed for the flights in Libya, it stripped NATO of mandate to execute military operation in Libya and took a row of sanctions off Libya, introduced under M. Gaddafi. Western politics were very optimistic about Libya's future. "The dark shadow of tyranny had passed away and now Libyan nation got a possibility to build democratic Libya... We are looking forward to the fastest possible formation of transition government and realization of the first free and fair elections", said B. Obama.

Though, further development of the postwar situation in Libya had shown there were no reasons for such optimism. For numerous Libyan clans and tribes official Benghazi was not an authority. The winners lacked unity. Yet before Tripoli was taken, sheikhs had started dividing control and authority; this fact was proved by the murder of Colonel Abdul Fatah Younis, commander of armed rebel forces.

There started armed conflicts among different rebel groupings, which were aimed at getting control over infrastructure objects, such as markets, roads, and training bases. Thus, February 1, 2012 in Tripoli there started fights with using anti-aircraft mounts and heavy machine guns between detachments of Mistara and Zintan. The officials of Foreign Affairs Ministry preferred not to interfere into the situation and confined themselves to oral appeals to the sides of the conflict. The fights between the tribes occurred out of the capital as well. In conditions like these there is nothing to say either about rise of living standards, or about human rights observances in Libya, as field commanders are full-value hosts on their territories. According to the UN data they created the whole chain of private prisons, where they keep about to eight thousand former M. Gaddafi's adherents.

Probably, intervention in Libya will be continued. After liquidation of M. Gaddafi Libya authorities took up the course directed on the islamisation of the country. Particularly, any law contradictory to Sharia Islamic Law automatically loses its legitimacy. Islamists' power is explained not only by the serious financing on the part of Saudi Arabia and Qatar. As the events in Afghanistan and Somali had shown islamists are the most organized ones under conditions of civil war. They started strengthening their influence in Libya at the beginning of the conflict. With the conclusion of civil war immigration of islamists to Libya increased. British media, referring to the government sources, informed that in the end of 2011 "the whole group of experienced soldiers, who were originally from Northern Africa and who had been having several bases in Afghan province of Kunar, left their encampments and went home" ${ }^{19}$. Islamists have got strong positions not only in Tripoli. In the birthplace of the Libyan revolution, Benghazi, a mass meeting of many thousands standing for introducing Sharia Islamic Law throughout whole Libya without referendum was held on January 21, 2012. The participants of the meeting even captured the building of the National Transitional Council. It was managed to calm down the demonstrators, but they partly fulfilled their goal: the meeting resulted

\footnotetext{
${ }^{19}$ H. Myrzajan, Syryjskyj ýtap "Arabskoj vesnü": vojna vmesto modernyzacyy. $<$ http://www.rusus.ru/?act=read\&id=324>
} 
into the resign of Vice Chairman of the National Transitional Council of Libya, Abdul Hafiz Ghoga, who was considered to be adherent of Europe.

It should be mentioned that the USA were satisfied with the final results the Libyan campaign first of all because they succeeded to make Europe take upon itself great part of expenses and responsibility for one of the global world democratization fronts. "This is the very type of world order, that I want to see, where there is not only the USA to sustain losses and square accounts, paying for common universal values, while others stand apart. But where we can say: the USA is the leader everywhere and we lead the way for others to follow us", said United States Secretary of State, G. Clinton.

And Secretary General of NATO claimed it "had been one of the most successful operations in NATO history". Though, analytics tend rather to call this operation Europe's embarrassment both in context of the fight for the preferences of Libya's new government and in military context. According to the words of Pentagon officials European NATO members had lacked reconnaissance platforms and aircrafts aerial refueling in Libya. The surprise of the operation was also a great lack of ammunition and equipment. In the case of execution of air-ground operation all these drawbacks would have unavoidably cause great human losses.

So in Libya Paris and London wanted to demonstrate that Europe is capable of maintaining major peacemaking operations independently, without the control of the United States. But the real progression of events proved the opposite and led to weakening of Europe's influence in the region.

Nevertheless, on the 4th of November, 2011, after the G-20 summit, President B. Obama and president of France N. Sarkozy celebrated the friendship of their peoples and the completion of military operation in Libya. Presidents greeted French and American soldiers and then delivered the speeches. "When you are back to the United States, you may tell your people that every time an American soldier dies during the operation at the other end of the world, the hearts of the French are in sympathy with his family. You have got a serious friend represented by France, though independent, having own ideas and temperament, but a faithful one", announced N. Sarkozy. In his turn, B. Obama highlighted that Libyan operation had become "the fastest mobilization in the history of NATO, 20 .

So, from the example of Libyan conflict it may be seen that the USA and the French Republic cooperate actively on the international stage, particularly in the Near East. They hold same positions in conflict situations and try to find ways to resolve them. And even though this is not caused by the willingness to close partnership every time, but rather by some external factors, it is clear that the Near East is quite an unstable region, and the United States and France will anyway have to cooperate in this direction.

In addition, both countries suffered losses after the military operation in Libya. In Tripoli, Libyan capital city, the embassy of France was attacked by the militant group in 2013. As a result two security guards were injured. It is not excluded, that the islamists, unsatisfied with the participation of France in the military operation in Mali, stand behind ${ }^{20}$ Presidents Sarkozy and Obama celebrate franco-american partnership. <http://ambafrance-
us.org/spip.php?article2858> 
the attack. Earlier Paris sent military forces to the African country, and after this it was managed to drive out the islamists to the North. It is not the first attack of diplomatic officials in Libya. In September 2012 the attack of American embassy in Benghazi resulted into the murder of American ambassador in Libya, C. Stevens, and three other American diplomats.

So, Franco-American cooperation is actual and necessary in solving conflicts and avoiding threats for the civil population.

Summing up, it must be mentioned that Franco-American cooperation during Arab revolutions in 2011 was quite fruitable. Libya was a "historical" operation from many perspectives. First of all, it was "historical" because of the fast reaction of international community. Secondly, for the first time since the creation of NATO European countries, especially France, who had not been supporting NATO's actions for a long time, take upon themselves $90 \%$ of armed activities.

It should be noted that from the 19th till the 31st of March 2011 American operation "Odyssey Dawn" and French "Operation Harmattan" worked together absolutely harmoniously and tried to keep the control over the part of Libya's territory and strengthen their legitimacy by doing so. Libyan situation showed the connection between the two countries. President N. Sarkozy said that the views of The USA and those of France were the same and lie in the fact that Colonel M. Gaddafi resigned and that the Libyan people had the right for democratic future.

Though, the fact, that France occupied the leader's position from the beginning of the Libyan conflict, is worth mentioning. The first air strikes on M. Gaddafi's military objects were performed by French air powers. As for the USA, American president did not participated actively in the solving of this conflict. First of all B. Obama took the office in the period of antimilitary mood existing in the American society; he took the position of a man who will radically change external policy of the USA and withdraw military forces from Iraq. He got Nobel Peace Prize in advance. So the president could hardly convince the voters that the USA must actively participate in another war.

Apart from that, the structure of the Libyan war differed from the military operation of NATO in the former Yugoslavia, and from the operation of the USA and their allies in Afghanistan and Iraq. For the first time, since the events of the Suez Crisis in 1956, Paris and London started considerable military and politic projects in Mediterranean Sea and took the leading role in the military operations. Great Britain and France seemed to overcome the results of the disruption of their colonial empires and renewed their statuses of great states, they had lost in 1950 .

Though, the participation of the French Republic in the Libyan conflict influenced the disposition of French people and N. Sarkozy's destiny. Mass media started focusing on the combative rhetoric of the French president, often criticizing his external policy.

Oleksiy Fenenko, the leading scientific coworker of the Institute of International Security Problems of Russian Academy of Sciences (IPMB RAS), had analyzed N. Sarkozy's actions and the role of the French Republic in the Libyan war. Firstly, in his opinion, Libyan war had shown inability of French Mediterranean Union project ${ }^{21}$. France

\footnotetext{
${ }^{21}$ A. Fenenko, Začem bombyt' Kaddafy? Lyvyjskaja operacyja ukrepl'aet NATO. 31.03.2011. <http://www.centrasia.ru/newsA.php?st=1301546340>
} 
traditionally place emphasis on the development of relations with the states of this region, and in the last years Mediterranean direction occupied more and more important place among French external policy interests, and the project of the creation of Mediterranean Union, though being not especially successful one, became N. Sarkozy's pet project. Although in 1995 France initiated the Barcelona process: dialogue between the EU and the other counties of the Mediterranean world. And at the first summit of Mediterranean Union in July 2008 in Paris France presented the supplement for creation a special EU security zone, independent from the USA and NATO. But the Libyan war changed the strategic position. Élysée Palace succeeded in overthrowing M. Gaddafi's regime not with the help of Mediterranean Union, but only in the frames of NATO operations. NATO operations take part in the cooperation of the US and the UK, two forces, which used to be main rivals of French initiative in the Mediterranean. It seemed like France did not manage to fulfill its role of Mediterranean Union leader independently from NATO. Though, since the presidency of Charles de Gaulle (1958-1969) Paris was concentrated on the creation of "European community", independent from the United States. Secondly, the Libyan war weakened the positions of France in Arab world. In 2000s Paris and Berlin suggested an alternative to the police of Washington in the Near East. Criticizing the military operation in Iraq, crisis over the Iraq nuclear program and favour of the US to Israel, France and Germany constantly offered peaceful alternative to the actions of the USA, the UK and Israel. After Libyan was Paris is regarded as "younger ally" of the USA in Arab world at the moment.

So despite anti-American disposition, French society realizes clearly the necessity of saving the partnership with the USA and American political elite, in its turn, understands the importance of saving France in the role of a partner.

European and American people have to work together to stand against the main global problems in the sphere of economy, security or fight against international terrorism. Libyan situation had demonstrated that European people, especially the French, can not only take part in administration and solvation of a serious crisis, but can also take the leading role when the USA have to concentrate their resources in a different place. This very balance between Europe and the United States will secure a long-term firmness of transatlantic relations.

\section{Bibliography:}

[1] Levyna K. Revolucyja v Lyvyy kak ynstrument stabylyzacyy ýkonomyky SŠA [Tekst], Molodoj učenüj, 2011, T.2.

[2] Notin J. Ch., La vérité sur notre guerre en Libye, Fayard, 2012.

[3] Snežanova L., Vojna v Lyvyy kak očerednoj ýtap peredela myra, Nacyonal'nüj ynstytut razvytyja sovremennoj ydeolohyy 2011

[4] Zvereva T., Sarkozy. Kaddafy, Meždunarodnaja žyzń, 2011, nr. 5.

\section{FRANCUSKO - AMERYKANSKIE RELACJE W KONTEKŚCIE WOJNY LIBIJSKIEJ 2011}

W artykule przeanalizowano stosunki francusko-amerykańskie w ramach wojny libijskiej. Autorka skupia się na stanowisku Republiki Francuskiej i Stanów Zjednoczonych w sprawie wydarzeń w krajach arabskich w 2011 roku i bada udział Francji w wojnie libijskiej. Zauważono, że zasady współpracy z krajami arabskimi i kontroli krajowych i 
zagranicznych strategii politycznych na Bliskim Wschodzie i w Afryce Północnej mają ogromne znaczenie dla stosunków międzynarodowych czołowych wykonawców, takich jak Francja i USA. Świadczy to o niejednoznacznych stosunkach między Francją i USA i często sprzecznych interesów tych państw. Kolejnym sprawdzianem zgodności stosunków francusko-amerykańskich był rok 2011. Podczas arabskich powstań USA i Francja wykazały się partnerstwem i potwierdziły swoje znaczenie na arenie światowej. Ich współpraca przyczyniła się do zakończenia dyktatury Muammara Kaddafiego. Autorka omówiła przyjęcie rezolucji w 1973 roku, przebieg operacji wojskowej i jego konsekwencje w Libii oraz obalenie reżimu Kaddafiego. Ponadto uważa się, że libijska sytuacja pokazała, że Republika Francuska nie może uczestniczyć w administracji oraz w rozwiązywaniu poważnego kryzysu, ale maja również wiodaca rolę na Bliskim Wschodzie i w Afryce Północnej. Autorka przedstawiła również współpracę francusko-amerykańską w operacjach wojskowych w Libii i korzyści z interwencji wojskowej dla Francji i USA.

Slowa kluczowe: stosunki francusko-amerykańskie, rozdzielczość 1973 roku, wojna libijska, Bliski Wschód

DOI:10.7862/rz.2013.hss.42

Tekst złożono w redakcji: listopad 2013.

Przyjęto do druku: styczeń 2014 